\section{Chamberless Healing for Small-scale Production of Grafted Tomato Transplants}

\author{
Tian Gong ${ }^{1}$, Xin Zhao ${ }^{1}$, Ashwin Sharma ${ }^{1}$, Jeffrey K. Brecht ${ }^{1}$, \\ and James Colee ${ }^{2}$
}

ADDITIONAL INDEX WORDs. adventitious roots, flowering, grafting, growth, humidity, photosynthesis, rootstock, scion, survival rate

SUMMARY. Interest is growing among small-scale growers in grafting tomato (Solanum lycopersicum) for improved crop productivity. Healing of newly grafted plants is often considered to be a critical process requiring a highly controlled environment. Setting up healing chambers and managing healing conditions can be major challenges for small-scale producers that limit graft survival and discourage further attempts at using grafting technology. Here, we demonstrate a simple "chamberless healing" strategy for grafted tomato plants using regular indoor conditions without the need to install and manage a sophisticated healing chamber. We hypothesize that tomato can form a high-quality graft in a healing environment with relative humidity below $70 \%$ and ambient temperatures between 22 and $25{ }^{\circ} \mathrm{C}$. 'Tribute' beefsteak tomato as the scion was grafted onto 'Estamino' rootstock in the 2018 experiment, whereas 'Multifort' and 'Shield RZ F1 (61-802)' were used as the rootstocks in the 2019 experiment. After grafting, the seedlings for the chamberless healing treatment were kept in uncovered seedling trays and misted with water two or three times per day. Seedlings in other treatments were placed in a humidity dome or wrapped chamber to maintain high humidity during the first few days after grafting. In the 2018 experiment, chamberless healing was compared with covered treatments with different ventilation times during the first few days after grafting. In the 2019 experiment, chamberless healing was compared with a standard graft healing chamber treatment to further validate its feasibility. In both 2018 and 2019 , all treatments showed high graft survival rates $(>85 \%)$ at 21 days after grafting (DAG), and plants from the chamberless healing treatment had a lower incidence of adventitious root growth than plants from other healing treatments $(0 \%$ to $7 \%$ vs. $33 \%$ to $78 \%)$. In the 2019 experiment, no differences in graft union strength, photosynthetic rate, biomass accumulation, or flowering time were observed between the chamberless and standard healing treatments. Plants with chamberless healing were slightly $(8 \%)$ shorter than the standard treatment at 21 DAG, but no difference was observed at 27 DAG. Although some additional management is required during healing to prevent water loss, the alternative chamberless system assessed in this study exhibited great potential to facilitate small-scale graft healing for producing grafted tomato transplants under standard indoor conditions without any sophisticated healing environment and management.

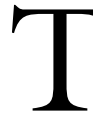

omato (Solanum lycopersicum) grafting has been widely used because of its major benefits in

Received for publication 30 July 2020. Accepted for publication 23 Oct. 2020.

Published online 14 December 2020

${ }^{1}$ Horticultural Sciences Department, University of Florida, Gainesville, FL 32611

${ }^{2}$ Statistics Consulting Unit, Institute of Food and Agricultural Sciences, University of Florida, Gainesville, FL 32611

This work is supported by the Specialty Crop Research Initiative grant no. 2016-51181-25404 from the U.S. Department of Agriculture National Institute of Food and Agriculture.

X.Z. is the corresponding author. E-mail: zxin@ufl. edu.

This is an open access article distributed under the CC BY-NC-ND license (https://creativecommons.org/ licenses/by-nc-nd/4.0/).

https://doi.org/10.21273/HORTTECH04707-20 conferring plant resistance to soilborne pathogens, alleviating the deleterious effects of abiotic stresses, and enhancing water and nutrient use efficiency (Singh et al., 2017). In the
United States, many small-scale organic vegetable growers graft plants on their own (Kubota et al., 2008) for using particular rootstock-scion combinations to deal with site-specific issues; however, they may not be able to produce high-quality grafted tomato plants (Meyer et al., 2017). Grafted tomato plants are usually kept in a healing chamber for 7 to $10 \mathrm{DAG}$ (Bausher, 2013; Hu et al., 2015). For the first several days, grafts are often placed in a high-humidity environment and ventilation is gradually increased (Fan et al., 2015). Grafted tomato typically requires 7 to $14 \mathrm{~d}$ to connect vascular bundles between the scion and rootstock plants (Fan et al., 2015), although the major hydraulic connections begin to function from 6 to 7 DAG (Turquois and Malone, 1996). It has also been suggested that vascular connection usually takes 5 to $8 \mathrm{~d}$ to form, and it takes $14 \mathrm{~d}$ for the graft union to fully heal (Johnson et al., 2016). Fernández-García et al. (2004) monitored root hydraulic conductance of grafted tomato plants at $4,8,12$, and $15 \mathrm{DAG}$ and observed a linear increase from 4 to $12 \mathrm{DAG}$ starting from 0 , but an evident increase was not observed after 12 DAG.

Many of the previous reports have indicated the importance of humidity level during the graft healing period on the survival and quality of grafted seedlings. According to Oda (2007), even a momentary drying of the cut surface can be lethal. Wei et al. (2018) tested three relative humidity $(\mathrm{RH})$ regimens, including $70 \%$ to $80 \%, 80 \%$ to $90 \%$, and $90 \%$ to $100 \%$, to demonstrate that $97 \%$ to $98 \%$ was the optimal RH for successful healing of grafted tomato seedlings, whereas $70 \%$ to $80 \%$ and $80 \%$ to $90 \%$ resulted in apparent wilting of grafted plants.

\begin{tabular}{llll}
\hline $\begin{array}{l}\text { Units } \\
\begin{array}{l}\text { To convert U.S. to SI, } \\
\text { multiply by }\end{array}\end{array}$ & U.S. unit & SI unit & $\begin{array}{l}\text { To convert SI to U.S., } \\
\text { multiply by }\end{array}$ \\
\hline 29.5735 & $\mathrm{fl} \mathrm{oz}$ & $\mathrm{mL}$ & 0.0338 \\
3.7854 & gal & $\mathrm{L}$ & 0.2642 \\
2.54 & inch(es) & $\mathrm{cm}$ & 0.3937 \\
25.4 & inch(es) & $\mathrm{mm}$ & 0.0394 \\
645.1600 & inch & $\mathrm{mm}$ & 0.0016 \\
4.4482 & lbf & $\mathrm{N}$ & 0.2248 \\
0.0254 & $\mathrm{mil}(\mathrm{s})$ & $\mathrm{mm}$ & 39.3701 \\
28.3495 & $\mathrm{oz}$ & $\mathrm{g}$ & 0.0353 \\
1 & $\mathrm{ppm}$ & $\mathrm{mg} \cdot \mathrm{L}^{-1}$ & 1 \\
1 & $\mathrm{ppm}$ & $\mu \mathrm{L} \cdot \mathrm{L}^{-1}$ & 1 \\
$\left({ }^{\circ} \mathrm{F}-32\right) \div 1.8$ & ${ }^{\circ} \mathrm{F}$ & ${ }^{\circ} \mathrm{C}$ & $\left({ }^{\circ} \mathrm{C} \times 1.8\right)+32$
\end{tabular}


Guan and Hallett (2016) recommended putting newly grafted tomato plants in an environment with $85 \%$ to $95 \% \mathrm{RH}$ for the first 48 to $72 \mathrm{~h}$. Vu et al. (2014) compared combinations of four temperatures and three $\mathrm{RH}$ levels on the survival rate of grafted tomato plants and found that at $23^{\circ} \mathrm{C}$ and $80 \% \mathrm{RH}$ plants had a higher survival rate than healing at $70 \%$ or $90 \% \mathrm{RH}$ at $23{ }^{\circ} \mathrm{C}$. Buajaila et al. (2018) investigated $100 \%$ and $50 \%$ $\mathrm{RH}$ and $0 \%, 25 \%$, and $50 \%$ light levels on eggplant (Solanum melongena), pepper (Capsicum annuum), and tomato graft survival rate. They found that at 21 DAG, when averaged over all crops tested, graft healing under $100 \% \mathrm{RH}$ had a higher survival rate than healing under $50 \% \mathrm{RH}$ regardless of the light level. Under $50 \% \mathrm{RH}$, the survival rate was highest with $25 \%$ light followed by $0 \%$ light, and $50 \%$ light treatment had only a $32 \%$ survival rate. However, Johnson and Miles (2011) suggested that high $\mathrm{RH}$ may not be essential for healing tomato grafts as they exhibited similarly high survival rates at average $\mathrm{RH}$ levels of $98 \%, 81 \%$, and $52 \%$. Masterson et al. (2016) also reported that high humidity $(>85 \% \mathrm{RH})$ may not be required for grafted tomato healing. Both studies used self-grafted tomato scion plants instead of grafted scion plants with commercial rootstocks. Moreover, they only documented the survival rate of grafts without an examination of grafted plant growth and flowering. Hence, more research is needed to further validate the feasibility of healing tomato grafts using lower RH levels and determine how low RH healing conditions impact the growth and development of grafted plants compared with grafts healed under standard healing conditions.

An extended period under high humidity also promotes the formation of adventitious roots from the tomato scion during graft healing (Guan and Hallett, 2016), which could lead to rootstock growth decline in grafted tomato seedlings or even grafting failure and rootstock death if adventitious roots grow into soil/medium (Meyer et al., 2017). Adventitious rooting from the scion could also allow soilborne pathogens to bypass the resistance of the rootstock and invade the scion, and removing adventitious roots requires extra labor and time. Moreover, keeping tomato plants in a high humidity environment for a long time may be conducive to disease development $(\mathrm{Vu}$ et al., 2014) and cause physiological disorders such as edema, which is irreversible (Johnson et al., 2016). Modifying humidity levels and duration during tomato graft healing could potentially help reduce scion adventitious root formation and increase grafted plant quality.

In this study, we tested a novel tomato graft healing method using a chamberless approach in a regular indoor ambient environment. The objectives were to compare the survival rate, adventitious root formation, and posthealing growth of grafted tomato seedlings between chamberless healing and standard healing chamber methods to explore the feasibility of chamberless healing to assist small-scale production of grafted tomato transplants.

\section{Materials and methods}

Experiments were carried out in Spring 2018 and Summer 2019. The 2018 experiment was a pilot study comparing a chamberless healing method with other healing treatments of grafted tomato. The 2019 experiment was designed to validate the efficacy of the chamberless healing method and compare it with the commonly used standard healing approach by examining the growth of healed grafted plants after the healing process.

2018 PILOT STUdy. The 'Tribute' beefsteak determinate tomato scion (Sakata Seed America, Morgan Hill, CA) was grafted onto the 'Estamino' tomato rootstock (Johnny's Selected Seeds, Winslow, ME) in the 2018 study. 'Estamino' and 'Tribute' were seeded on 29 and 31 Jan., respectively. Seeds were sown into 72-cell polystyrene foam trays (Speedling, Ruskin, FL) filled with organic potting mix (Natural \& Organic Potting Mix; Sun Gro Horticulture, Agawam, MA). Organic $5 \mathrm{~N}-0.4 \mathrm{P}-0.8 \mathrm{~K}$ liquid fish fertilizer (Aqua Power; JH Biotech, Ventura, CA) was applied on a weekly basis (7 and 20 Feb.) at a nitrogen $(\mathrm{N})$ concentration of 200 $\mathrm{mg} \cdot \mathrm{L}^{-1}$. Plants were grafted on 24 Feb. (0 DAG) using the splice grafting method (Guan and Hallett, 2016) when the stem diameter reached $2 \mathrm{~mm}$ and 'Tribute' plants had two to three true leaves (leaf length $>5$ $\mathrm{cm})$. Cuts were made below the cotyledon of the rootstock and above the cotyledon of the scion. All grafts were carefully made by a well-trained person to eliminate the influence of grafting quality on graft survival. After grafting, plants were healed in an indoor laboratory at $24^{\circ} \mathrm{C}$.

Grafted plants within the same healing treatment were placed in a plastic webbed tray (790910C1020 solid sided; T.O. Plastics, Clearwater, $\mathrm{MN}$ ) with clear plastic film covering the bottom to prevent ventilation. The trays were covered with a clear humidity dome (Mondi propagation dome; Greenhouse Megastore, Danville, IL), except in the chamberless treatment, where the dome was not applied. All the trays were placed directly on the room floor. A $25-\mathrm{mL}$ beaker of water was also placed on each tray to help maintain humidity. This pilot experiment was arranged in a randomized complete block design with three blocks (replications) and five plants per treatment per block. We purposely used a small number of grafted plants in this pilot study to ensure the consistency and quality of making the tomato grafts. There were seven graft healing treatments, including the chamberless treatment, and six treatments with the healing chamber. Plants were healed in the chamberless treatment for $7 \mathrm{~d}$ before moving to the greenhouse. The healing chamber treatments involved two factors for humidity manipulation, including the length of plant healing time without ventilation $(2,3$, or $4 \mathrm{~d})$ and the pace of ventilation management (slow or fast), during which the humidity dome was removed completely. For the slow ventilation pace, the ventilation time was $30 \mathrm{~min}$ for $2 \mathrm{~d}$ followed by $60 \mathrm{~min}$ for the next $2 \mathrm{~d}$ and 120 min for the last $2 \mathrm{~d}$ before moving grafts to the greenhouse. For the fast ventilation pace, the ventilation time was $60 \mathrm{~min}$ for $2 \mathrm{~d}$ followed by 120 min for $3 \mathrm{~d}$ before moving grafts to the greenhouse. For example, the $2 \mathrm{~d}$ Slow treatment indicated that plants were covered by the humidity dome without ventilation for the first 2 $\mathrm{d}$ after grafting, and at 3 and 4 DAG, humidity dome cover was removed for $30 \mathrm{~min}$ at noon each day. The humidity dome was then removed for $60 \mathrm{~min}$ at 5 and 6 DAG 
and for $120 \mathrm{~min}$ at 7 and 8 DAG. From the first ventilation day, the two ventilation holes at the top of the humidity dome were kept open for all the healing chamber treatments. At $0 \mathrm{DAG}$, the grafted plants were left in darkness. At 1 and 2 DAG, plants were exposed to $6 \mathrm{~h}$ of light at 7 $\mu \mathrm{mol} \cdot \mathrm{m}^{-2} \cdot \mathrm{s}^{-1}$ photosynthetic photon flux density (PPFD) at the canopy level provided by fluorescent lights. Starting from 3 DAG, light was increased to 8 h per day (from 9:00 AM to 5:00 PM), and all treatments except the chamberless healing treatment were sprayed with deionized (DI) water during ventilation. The chamberless treatment plants were sprayed twice per day at 9:00 AM and 5:00 PM. Water was also applied occasionally to the soil as needed. During the healing process, ambient light intensity, $\mathrm{RH}$, and air temperature were recorded every $30 \mathrm{~min}$ using data loggers (HOBO model H08-002-02; Onset Corp., Bourne, MA). When the healing period ended, plants were moved to a greenhouse according to the graft healing experimental design for the final assessment of graft survival. Plants were placed in a $50 \%$ shaded area for $4 \mathrm{~d}$ and then moved to a full sun environment. From $11 \mathrm{DAG}$, plants were fertilized with $5 \mathrm{~N}-0.4 \mathrm{P}-$ $0.8 \mathrm{~K}$ organic liquid fish fertilizer at $200 \mathrm{mg} \cdot \mathrm{L}^{-1} \mathrm{~N}$ every $5 \mathrm{~d}$ until survival rate assessment.

2019 FOLLOW-UP EXPERIMENT. To better validate the chamberless healing method, two tomato rootstocks, 'Multifort' (DeRuiter Seeds, Columbus, $\mathrm{OH}$ ) and 'Shield RZ F1 (61-802)' ['Shield' (Rijk Zwaan USA, Salinas, CA)], were tested in the follow-up experiment in 2019. 'Multifort' is a vigorous tomato rootstock, whereas 'Shield' has medium vigor, according to the tomato rootstock cultivar description by seed companies.

'Tribute' as the scion was grafted onto 'Multifort' and 'Shield', respectively, with self-grafted 'Tribute' as the control. Similar to the 2018 pilot study, one well-trained person conducted all the grafting work to ensure consistent quality. Two healing treatments were investigated, including a chamberless treatment and the standard healing treatment using a healing chamber. This experiment was arranged in a randomized complete block design with
4 blocks (replications) and 18 plants per treatment per block. Rootstocks and scion were seeded on 10 and 14 June 2019, respectively, using 72 -cell polystyrene foam trays filled with commercial potting medium (Professional Growing Mix; Sun Gro Horticulture). When the first true leaf emerged, seedlings were fertilized with $20 \mathrm{~N}-8.8 \mathrm{P}-16.6 \mathrm{~K}$ water-soluble fertilizer (Scotts, Marysville, $\mathrm{OH}$ ) at $50 \mathrm{mg} \cdot \mathrm{L}^{-1} \mathrm{~N}$ every $3 \mathrm{~d}$. Plants were grafted on 2 July (0 DAG) using the splice method. For both rootstock and scion plants, the cut was made below the cotyledons to match the stem diameter. After grafting, all plants were kept in a chrome wire shelving unit in the laboratory at $24{ }^{\circ} \mathrm{C}$ with an 8 -h light period (9:30 AM to $5: 30 \mathrm{pM}$ ) and $64 \mu \mathrm{mol} \cdot \mathrm{m}^{-2} \cdot \mathrm{s}^{-1}$ PPFD at the canopy level provided by fluorescent lights. The chamberless treatment plants were placed in a $45 \times 65-\mathrm{cm}$ tray (Molded Fiber Glass Tray Co., Linesville, PA) with a layer of wetted germination paper (Anchor Paper Co., St. Paul, MN) at the bottom. A $25-\mathrm{mL}$ beaker of DI water was placed next to the plants. The wetted germination paper and the beaker of water were intended to provide moisture to the air around the healing plants. For the chamberless treatment, DI water was sprayed on the plants at $\approx 9: 00 \mathrm{AM}, 12: 30 \mathrm{PM}$, and 5:00 PM for the first $4 \mathrm{~d}$, then sprayed twice per day in the morning and the evening, respectively, from 5 to $7 \mathrm{DAG}$ and only once in the morning from 8 to 10 DAG. Water was also applied occasionally to the soil as needed. The wetted germination paper was removed at 8 DAG. For the standard healing treatment, plants were also placed on a layer of wetted germination paper but were sealed in a chamber made by wrapping the shelving unit with 0.80 -mil plastic film (Econo-Wrapper; Uline Corp., Pleasant Prairie, WI). The film was cut open at 4 DAG to gradually decrease the humidity, and it was completely removed at 8 DAG. From 4 to 8 DAG, DI water was also sprayed once per day on grafted plants in the standard healing treatment to reduce the shock of decreasing humidity. All treatments remained in ambient humidity from 8 to 10 DAG. All grafted plants were then moved to a greenhouse and fertilized immediately at 10
DAG. The average day and night temperatures in the greenhouse were 28.57 and $24.61{ }^{\circ} \mathrm{C}$, respectively, during 10 to 52 DAG. During the healing process, light intensity, $\mathrm{RH}$, and air temperature were recorded via data loggers for each healing treatment.

Plants were fertilized with $20 \mathrm{~N}-$ 8.8P-16.6K water-soluble fertilizer at $200 \mathrm{mg} \cdot \mathrm{L}^{-1} \mathrm{~N}$ every $5 \mathrm{~d}$ during 10 to 21 DAG. At 21 DAG, the graft survival rate was assessed. After that, all surviving plants were transplanted into 15-cell trays $(730630 \mathrm{C}$ Sheet Pots, T.O. Plastics) using conventional growing mix (Metro-Mix; Sun Gro Horticulture). At 30 DAG, five plants in each treatment in each block were randomly selected and transplanted into 2 -gal black plastic pots $(600 \mathrm{C}$; Hummert International, Earth City, MO), which were placed on the greenhouse bench at 12 -inch plant spacing. This greenhouse pot study followed a randomized complete block design with four blocks (replications). Plants were irrigated daily with a nutrient solution $(20 \mathrm{~N}-$ $8.8 \mathrm{P}-16.6 \mathrm{~K}$ at $200 \mathrm{mg} \cdot \mathrm{L}^{-1} \mathrm{~N}$ ) by placing one $0.5 \mathrm{gal} / \mathrm{h}$ emitter (Woodpecker Pressure Compensating Junior Dripper; Netafim USA, Fresno, CA) in each pot. Irrigation occurred twice per day at 8:00 AM and 2:00 PM for $2 \mathrm{~min}$, then increased to 3 min from 35 DAG. Plants were not pruned, but each plant was supported by the rollerhook assembly (FarmTek, Dyersville, IA) hanging from a cable above. The experiment was ended when the first flower on each plant opened. A biological insecticide (DiPel PRO DF; Valent BioSciences, Libertyville, IL) and insecticidal soap (Insect Killing Soap Concentrate II; Organic Safer Brand, Lititz, PA) were sprayed at 38 and $45 \mathrm{DAG}$, respectively, for managing fall armyworm (Spodoptera frugiperda) and silverleaf whitefly (Bemisia tabaci).

SURVIVAL RATE AND ADVENTITIOUS ROOT ASSESSMENT. For both experiments, the survival rate of grafted plants was assessed at 21 DAG because a decrease in survival rate has been reported to occur from 11 to 21 DAG (Buajaila et al., 2018). Plants with a completely wilted scion were considered to be dead, and all others were considered to have survived (Hu et al., 2016). For both experiments, grafted plants were checked daily after grafting until 
they were moved to a greenhouse. The time when adventitious roots from scions first appeared and the incidence of plants developing adventitious roots (calculated by the percentage of the number of plants showing adventitious roots out of the total number of plants grafted) were recorded from 3 to 8 DAG in both 2018 and 2019 experiments. It was assumed that adventitious rooting incidence would gradually increase over the duration of the healing period. Plants were counted as exhibiting adventitious rooting only if root primordia developed into a $1-\mathrm{mm}$ or longer root. Adventitious rooting of all healed plants was assessed at 21 DAG in the 2019 experiment following a rating scale developed by Meyer et al. (2017). Adventitious roots were first classified according to their length as trace roots $(<2 \mathrm{~mm})$, small roots $(2 \mathrm{~mm} \leq$ length $<5 \mathrm{~mm})$, medium roots ( $5 \mathrm{~mm} \leq$ length $<10 \mathrm{~mm}$ ), or large roots $(\geq 10 \mathrm{~mm})$. Then each plant was rated using a 0 to 10 scale, with $0=$ no adventitious roots, $1=\operatorname{trace} \operatorname{root}(\mathrm{s})$ only, $2=\geq 1$ small $\operatorname{root}(\mathrm{s})$ and any trace $\operatorname{root}(\mathrm{s}), 3=1$ medium root and any small or trace $\operatorname{root}(\mathrm{s}), 4=$ multiple medium roots and any small or trace $\operatorname{root}(\mathrm{s}), 5=1$ large root and any additional $\operatorname{root}(s)$ but none in the soil, $6=$ multiple large roots and any additional root(s) but none in soil, $7=$ 1 root in soil and any small or trace $\operatorname{root}(\mathrm{s}), 8=1$ root in soil and any medium or large $\operatorname{root}(\mathrm{s}), 9=$ multiple roots in soil and any additional $\operatorname{root}(\mathrm{s})$, and $10=$ multiple roots in soil, which caused failure of rootstock growth.

EVALUATION OF GRAFT UNION STRENGTH. For the 2019 experiment, the strength of the graft union was tested at 20 DAG on three surviving plants per treatment per block, following the protocol of Lee et al. (2016) with modifications. The grafted plant was horizontally fixed within a frame consisting of two clips $3.3 \mathrm{~cm}$ apart. The graft union was centered between the two clips and oriented so that the angle of the cut appeared as in a " $\mathrm{Z}$ " shape when viewed from the side. A texture analyzer (TA-HD plus; Texture Technologies Corp., Scarsdale, NY) was configured with a cylindrical probe (12.80 $\mathrm{mm}$ diameter). The cylinder was oriented horizontally to act as a blunt-edged blade when contacting the grafted stem. The apparatus was set to move downward at a speed of 1 $\mathrm{mm} \cdot \mathrm{s}^{-1}$ during the contact with the stem until the graft union was completely broken. The maximum force in Newtons measured was used to estimate the strength of the graft union.

Plant early growth and DEVELOPMENT MEASUREMENTS. In 2018, plant height and stem diameter were measured on three plants per treatment per block at 21 DAG. In 2019, plant height, stem diameter, leaf number, and leaf chlorophyll content index were measured on five plants per treatment per block at 21 DAG and 27 DAG. Plant height was measured from the soil surface to the top of the meristem, and stem diameter was measured at $1 \mathrm{~cm}$ above the graft union. Leaves with a length $>5 \mathrm{~cm}$ were counted for leaf number. Leaf chlorophyll content index was measured with a chlorophyll meter (SPAD 502 Plus; Spectrum Technologies, Aurora, IL) by averaging the readings of leaflets of the third and fourth true leaves.

In 2019, plants were destructively sampled at 29 DAG for assessing plant biomass and leaf area at an early vegetative growth stage. All tissues below the graft union were considered as the root part in this assessment. Leaf number (leaf length $\geq 5 \mathrm{~cm}$ ) was counted and leaves and stems were separated for measuring fresh weight (FW). Leaf area was determined by scanning leaves with a leaf area meter (LI-3100; LI-COR Biosciences, Lincoln, NE). Roots were washed and the FW recorded. Leaves, stems, and roots were dried at $75{ }^{\circ} \mathrm{C}$ for $7 \mathrm{~d}$ until constant weight to determine dry weight (DW). After transplanting to larger pots at 30 DAG, plants were checked daily and the time when the first flower opened was documented (in DAG). In addition, the number of flowers in the first inflorescence was recorded. Flowering time, flower number in the first inflorescence, plant height, stem diameter above the graft union, leaf number, and leaf chlorophyll content index were measured at the flowering stage when the first flower opened.

GAS EXCHANGE MEASUREMENTS. Gas exchange was monitored on the top leaflet of the fourth true leaf at 27 DAG (plants in blocks 1 and 2 measured) and 28 DAG (plants in blocks 3 and 4 measured) from 10:00 AM to 2:30 PM on three plants per treatment per block using an open gas exchange system (LI-6800, LI-COR Biosciences $)$. Transpiration rate $\{\mathrm{E}$ [millimoles water $\left(\mathrm{H}_{2} \mathrm{O}\right)$ per square meter per second]\}, net carbon dioxide $\left(\mathrm{CO}_{2}\right)$ assimilation rate $[\mathrm{A}$ (micromoles $\mathrm{CO}_{2}$ per square meter per second)], intercellular $\mathrm{CO}_{2}[\mathrm{Ci}(\mathrm{mi}-$ cromoles $\mathrm{CO}_{2}$ per mole air)], and stomatal conductance to water vapor [gsw (moles $\mathrm{H}_{2} \mathrm{O}$ per square meter per second)] were measured. The following basic settings were applied: $P P F D$ at $600 \mu \mathrm{mol} \cdot \mathrm{m}^{-2} \cdot \mathrm{s}^{-1}, \mathrm{CO}_{2}$ concentration at $400 \mathrm{ppm}$, vapor pressure deficit (VPD) at 0.87 to $1.25 \mathrm{kPa}$, and air temperature at 30 to $31^{\circ} \mathrm{C}$. Instantaneous water use efficiency [iWUE (micromoles $\mathrm{CO}_{2}$ per millimole $\mathrm{H}_{2} \mathrm{O}$ ) was calculated as $\mathrm{A} / \mathrm{E}$ (Yang et al., 2019). Stomatal conductance to $\mathrm{CO}_{2}$ [gs (moles $\mathrm{CO}_{2}$ per square meter per second)] was calculated as $g_{\mathrm{sw}} / \mathbf{1 . 6}$ (Gago et al., 2014).

Statistical analyses. Given that the graft survival rates in both experiments were relatively high and the variability was not sufficient to run the generalized linear mixed model, we ignored the block factor and used Fisher's exact test $(\alpha=0.05)$ to examine whether the graft survival rate differed between treatments using JMP Pro 15 (SAS Institute, Cary, NC). Because adventitious root incidence was low and near 0 in some treatments across all observation days, a Bayesian logistic model was chosen to determine the difference in adventitious root incidence between treatments in both 2018 and 2019 experiments using SAS (version 9.4 for Windows, SAS Institute). All other parameters in both experiments were analyzed following a randomized complete block design. Square root transformation was used to help normalize the distribution of the data as needed for meeting the assumption of a generalized linear mixed model. In the 2018 experiment, no variable was transformed, whereas the data for leaf number, stem FW, leaf DW, and average flower number were transformed in the 2019 experiment. When data transformation was conducted for statistical analysis, the original data were used to present the final results. The GLIMMIX procedure (SAS version 9.4 for Windows) was used to estimate the impact of different rootstock-scion combinations and different healing conditions on the plant growth and development parameters measured. 
Fisher's least significant difference test $(\alpha=0.05)$ was conducted for multiple comparisons of different measurements among treatments.

\section{Results and discussion}

Graft Healing. The air temperature and $\mathrm{RH}$ of the chamberless healing treatments during the graft healing process were similar in the 2018 and 2019 experiments. In 2018 , the temperature of the chamberless treatment was (mean $\pm \mathrm{SD}$ ) $22.1 \pm 0.6{ }^{\circ} \mathrm{C}$ and the $\mathrm{RH}$ was $61.6 \% \pm 2.2 \%$ (data not shown). In 2019 , temperatures around the plants in the two healing treatments were between 22.7 and $24.7^{\circ} \mathrm{C}$. For the chamberless healing treatment, the $\mathrm{RH}$ was $57.7 \% \pm 2.8 \%$ throughout the healing period. With respect to the standard healing treatment, the $\mathrm{RH}$ at 0 to $3 \mathrm{DAG}$ was $99.1 \% \pm 0.5 \%$ due to the lack of ventilation, whereas it decreased to $82.5 \% \pm 4.7 \%$ during 4 to 7 DAG when the membrane was cut open. By 8 to $10 \mathrm{DAG}$, the $\mathrm{RH}$ of the standard healing treatment reached $54.8 \%$ to $65.3 \%$, which was similar to the chamberless healing treatment (Fig. 1).

In both experiments, all treatments achieved relatively high graft survival rates, ranging from $80 \%$ to $100 \%$, and no significant difference was detected between treatments (Table 1). The results indicate that

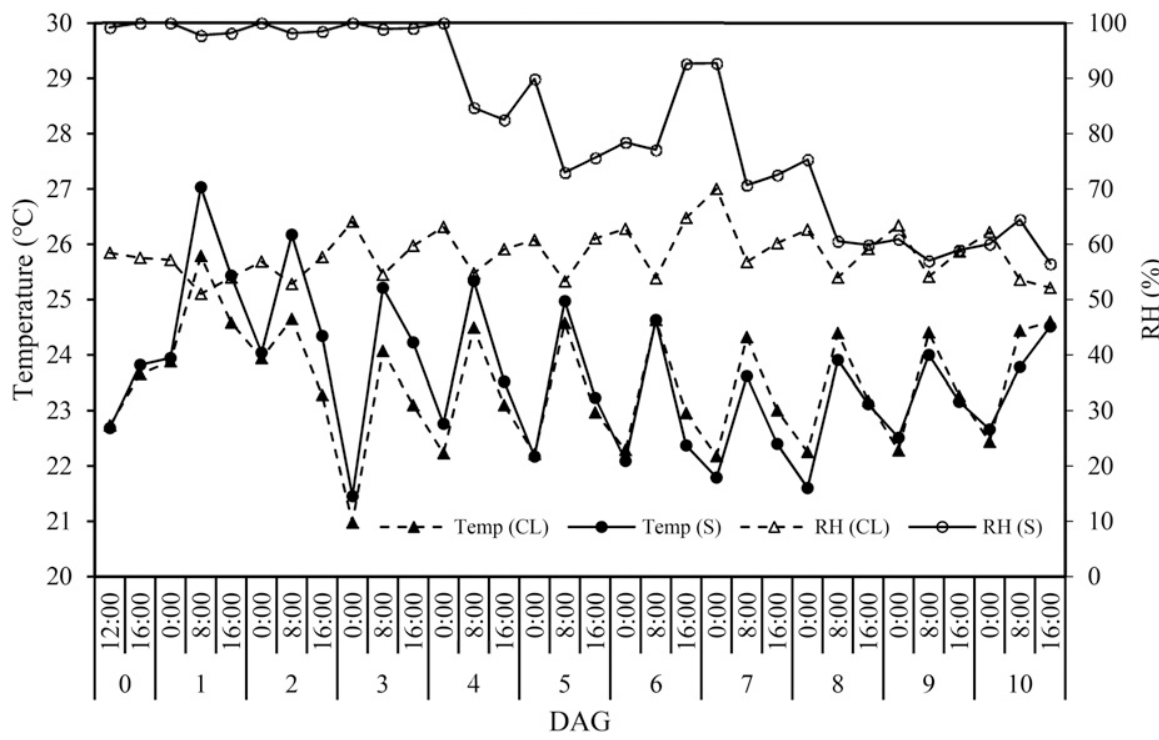

Fig. 1. Air temperature and relative humidity $(\mathrm{RH})$ averaged over 8 -h periods for the two tomato healing treatments in the 2019 experiment from $0 \mathrm{~d}$ after grafting (DAG) to $10 \mathrm{DAG} ; \mathrm{CL}=$ chamberless healing treatment; $S=$ standard healing chamber treatment; Temp $=$ temperature. $\left(1.8 \times{ }^{\circ} \mathrm{C}\right)+32={ }^{\circ} \mathrm{F}$.
$\mathrm{RH} \approx 55 \%$ to $65 \%$ during the healing period may not prevent callus formation between rootstock and scion (Martínez-Ballesta et al., 2010). Our results are in agreement with Johnson and Miles (2011) and Masterson et al. (2016), who also found that grafted tomato seedlings can tolerate lower RH during healing. Johnson and Miles (2011) showed that grafted tomato survival rate was $>90 \%$ under $52.6 \% \mathrm{RH}$ and $23.3{ }^{\circ} \mathrm{C}$, and Masterson et al. (2016) reported a 91\% survival rate when average $\mathrm{RH}$ was $48.4 \%$ and average temperature was $20.8^{\circ} \mathrm{C}$ in a greenhouse in Manhattan, KS. However, our results differed from that of Buajaila et al. (2018), who demonstrated a lower survival rate of grafted tomato at $50 \% \mathrm{RH}$ study, the actual $\mathrm{RH}$ of the $50 \% \mathrm{RH}$ treatment fluctuated between $42 \%$ to $49 \%$ during the first $4 \mathrm{DAG}$, which might have been too low to heal the grafts. Wei et al. (2018) reported graft survival rates of $77.8 \%$ and $86.1 \%$ for two tomato scions when plants were healed under $70 \%$ to $80 \%$ $\mathrm{RH}$, but the survival rate reached $100 \%$ under $90 \%$ to $100 \% \mathrm{RH}$. This could be attributed to the higher light intensity $\left(150 \mu \mathrm{mol} \cdot \mathrm{m}^{-2} \cdot \mathrm{s}^{-1}\right)$ and the prolonged photoperiod $(16 \mathrm{~h})$ used during the healing period because these conditions likely promoted transpiration and could have caused compared with $100 \% \mathrm{RH}$. In their more stress to the grafted plants under low humidity. We observed similar graft survival rates between different rootstock-scion combinations in the 2019 experiment, which was consistent with the study of $\mathrm{Vu}$ et al. (2014), who grafted one tomato scion with four rootstocks and showed survival rates from $72 \%$ to $80 \%$. 'Shield' and 'Multifort' rootstocks used in our experiment differ considerably in their growth vigor according to the seed companies and our observations (unpublished data), and the grafting results showed that rootstock vigor did not affect survival rate under chamberless healing conditions (Table 1 ).

According to Wei et al. (2018), wilting of grafted tomato seedlings was also observed at $3 \mathrm{DAG}$ under the $70 \%$ to $80 \% \mathrm{RH}$ and $80 \%$ to $90 \% \mathrm{RH}$

Table 1. Survival rate of grafted 'Tribute' tomato seedlings in different healing treatments at 21 $\mathrm{d}$ after grafting in the $\mathbf{2 0 1 8}$ and 2019 experiments.

\begin{tabular}{|c|c|}
\hline Treatment & Survival rate (\% \\
\hline \multicolumn{2}{|c|}{2018} \\
\hline Chamberless $^{z}$ & $93.0 \mathrm{a}^{\mathrm{y}}$ \\
\hline 2d-Slow & $100.0 \mathrm{a}$ \\
\hline 3d-Slow & $80.0 \mathrm{a}$ \\
\hline 4d-Slow & $87.0 \mathrm{a}$ \\
\hline $2 \mathrm{~d}$-Fast & $87.0 \mathrm{a}$ \\
\hline $3 \mathrm{~d}$-Fast & $93.0 \mathrm{a}$ \\
\hline 4d-Fast & $87.0 \mathrm{a}$ \\
\hline$P$ value & 0.999 \\
\hline \multicolumn{2}{|c|}{2019} \\
\hline $\mathrm{Sh}+\mathrm{T}(\mathrm{CL})^{\mathrm{x}}$ & $100.0 \mathrm{a}$ \\
\hline $\mathrm{M}+\mathrm{T}(\mathrm{CL})$ & $100.0 \mathrm{a}$ \\
\hline $\mathrm{T}+\mathrm{T}(\mathrm{CL})$ & $98.6 \mathrm{a}$ \\
\hline $\mathrm{Sh}+\mathrm{T}(\mathrm{S})$ & $97.2 \mathrm{a}$ \\
\hline $\mathrm{M}+\mathrm{T}(\mathrm{S})$ & $98.6 \mathrm{a}$ \\
\hline $\mathrm{T}+\mathrm{T}(\mathrm{S})$ & $100.0 \mathrm{a}$ \\
\hline$P$ value & 1.000 \\
\hline
\end{tabular}

${ }^{\mathrm{z}}$ In 2018 , the healing chamber treatments involved two factors for humidity manipulation, including the length of plant healing time without ventilation $(2,3$, or $4 \mathrm{~d}$ ) and the pace of ventilation management (Slow or Fast) during which the humidity dome was removed completely. For the slow ventilation pace, the ventilation time was $30 \mathrm{~min}$ for $2 \mathrm{~d}$ followed by 60 $\mathrm{min}$ for the next $2 \mathrm{~d}$ and $120 \mathrm{~min}$ for the last $2 \mathrm{~d}$ before moving grafts to the greenhouse. For the fast ventilation pace, the ventilation time was $60 \mathrm{~min}$ for 2 $\mathrm{d}$ followed by $120 \mathrm{~min}$ for $3 \mathrm{~d}$ before moving grafts to the greenhouse.

y'The block factor was not considered in the Fisher's exact test used to examine whether the graft survival rate differed between treatments. Means followed by the same letter are not significantly different at $P \leq$ 0.05 according to Fisher's exact test.

${ }^{\mathrm{x}} \mathrm{Sh}+\mathrm{T}=$ 'Tribute' grafted onto 'Shield'; $\mathrm{M}+\mathrm{T}=$ 'Tribute' grafted onto 'Multifort'; $\mathrm{T}+\mathrm{T}=$ self-grafted 'Tribute'; CL = chamberless healing treatment; $\mathrm{S}=$ standard healing chamber treatment. 
treatments. In our 2018 experiment, wilting did not occur in the chamberless healing treatments. However, for all other treatments, temporary wilting was observed $\approx 30$ min after the dome was removed for the first two ventilation periods. The plants recovered when the dome was put back. In the 2019 experiment, wilting was observed during 1 to $4 \mathrm{DAG}$ in the chamberless healing treatment, but plants recovered thereafter (Fig. 2). Compared with the 2018 experiment, light intensity during healing was much greater in 2019 , which may have contributed to more water loss that led to temporary wilting. Temporary wilting of the grafted tomato plants under the increased light intensity in the 2019 experiment supports the idea that proper management of light conditions during graft healing may contribute to high-quality healing (Buajaila et al., 2018; Lee et al., 2016). It has been reported that signal exchange between rootstock and scion could begin at $1 \mathrm{DAG}$, with vascular reconnection being initiated at $2 \mathrm{DAG}$, and the transport function of vascular bundles may recover at as early as 3 DAG (Yin et al., 2012), which could partially explain the lack of wilting observed in grafted tomato seedlings at $4 \mathrm{DAG}$ and thereafter in the present study.

The two experiments showed a consistent pattern in that the chamberless healing treatment delayed or even prevented adventitious root formation from the scion. For most of the healing chamber treatments, adventitious rooting from scion began to appear $\approx 4 \mathrm{DAG}$, peaked at $6 \mathrm{DAG}$, and leveled off thereafter, which could be due to the increased ventilation. From 6 to 8 DAG, all healing chamber treatments had higher adventitious root incidence than the

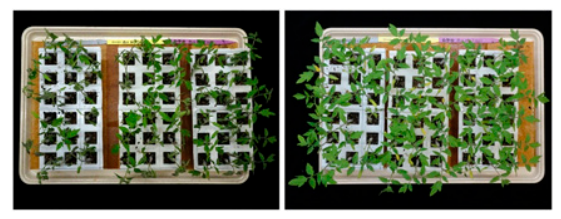

Fig. 2. Grafted tomato seedlings in the chamberless healing treatment at $24 \mathrm{~h}$ after grafting (left: photo taken on 3 July) and at $96 \mathrm{~h}$ after grafting (right: photo taken on 6 July) in the 2019 experiment. chamberless treatment in the 2018 experiment except that $2 \mathrm{~d}$-Slow and chamberless treatments had similar adventitious root incidences at 8 DAG (Fig. 3). In the 2019 experiment, all rootstock-scion combinations in the chamberless healing treatment had lower adventitious root incidences than those healed under standard healing chamber conditions between 4 and 8 DAG. The two rootstocks also showed differential impacts on adventitious root formation from the scion under standard healing chamber conditions. 'Shield' led to a higher adventitious root
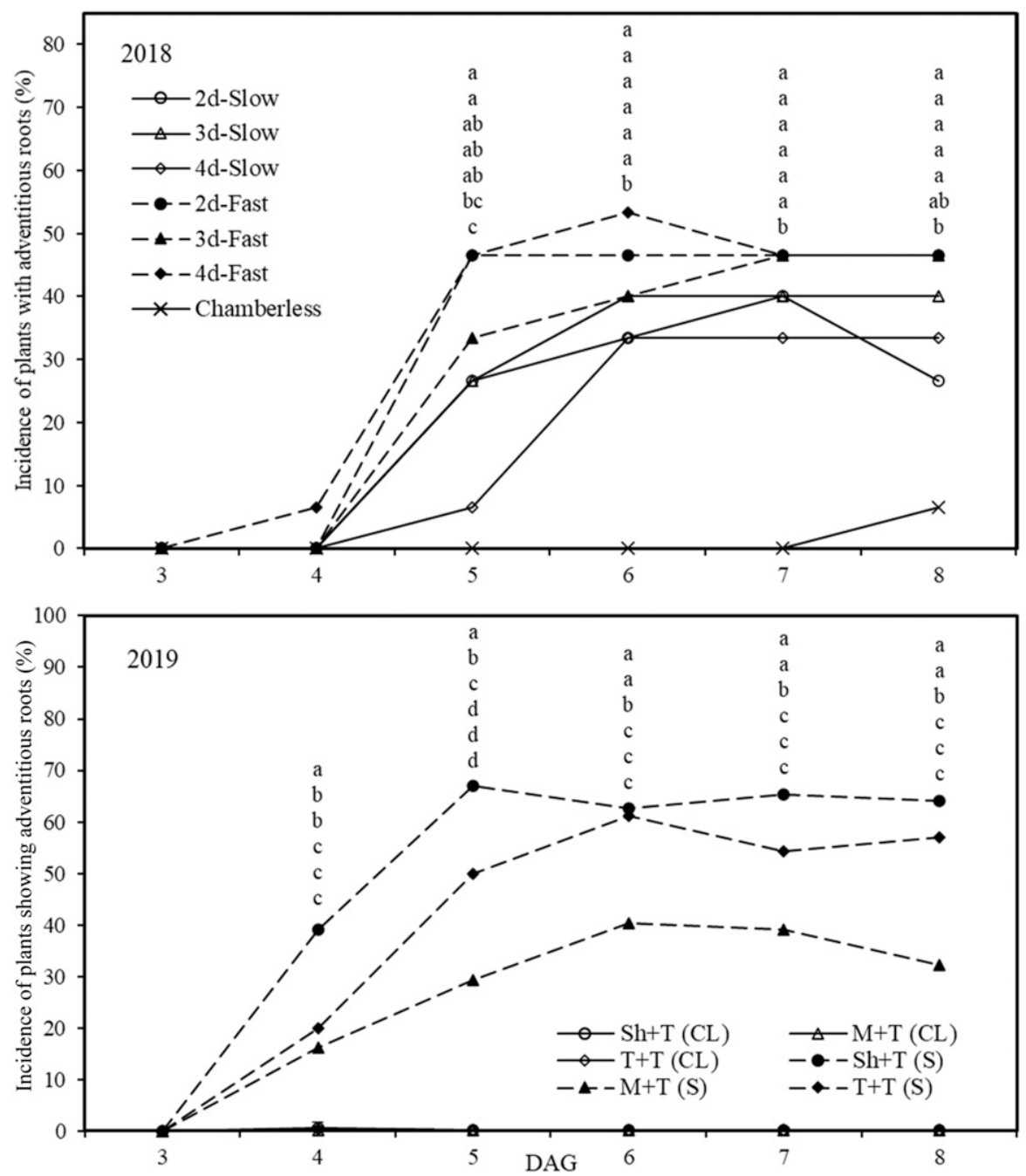

Fig. 3. Incidence of grafted 'Tribute' tomato seedlings with adventitious roots from scions during 3 to $8 \mathrm{~d}$ after grafting (DAG) in 2018 and 2019 experiments. Adventitious root incidence is calculated as the percent of the number of plants showing adventitious roots out of the total number of grafted plants. In the 2018 experiment, The healing chamber treatments involved two factors for humidity manipulation, including the length of plant healing time without ventilation $(2,3$, or $4 \mathrm{~d}$ ) and the pace of ventilation management (slow or fast) during which the humidity dome was removed completely. For the slow ventilation pace, the ventilation time was $30 \mathrm{~min}$ for $2 \mathrm{~d}$ followed by $60 \mathrm{~min}$ for the next $2 \mathrm{~d}$ and 120 min for the last $2 \mathrm{~d}$ before moving grafts to the greenhouse. For the fast ventilation pace, the ventilation time was $60 \mathrm{~min}$ for $2 \mathrm{~d}$ followed by $120 \mathrm{~min}$ for $3 \mathrm{~d}$ before moving grafts to the greenhouse. In the 2019 experiment, $\mathrm{Sh}+\mathrm{T}=$ 'Tribute' grafted onto 'Shield'; $M+T=$ 'Tribute' grafted onto 'Multifort'; T + T = self-grafted 'Tribute'; $C L$ = chamberless healing treatment; $S$ = standard healing chamber treatment. Values with the same letter at the same DAG do not differ significantly at $P \leq 0.05$ according to Bayesian logistic model. 
incidence compared with 'Multifort' throughout the healing process. At 8 DAG, 'Tribute' grafted onto 'Multifort' had a lower adventitious root incidence than self-grafted 'Tribute' and 'Tribute' grafted with 'Shield'. Moreover, healing conditions markedly affected adventitious root ratings at 21 DAG in the 2019 experiment (Table 2). Plants in standard healing conditions showed a 10 -fold increase in adventitious root ratings compared with grafted plants in the chamberless healing treatment. Rootstock-scion combinations also affected the adventitious root development. Plants grafted with 'Shield' showed a higher adventitious root rating compared with plants grafted with 'Multifort', but they did not differ from selfgrafted 'Tribute'.

The strength of the graft union was unaffected by rootstock-scion combinations or healing treatments (Table 2), suggesting that chamberless healing did not negatively affect

Table 2. Effects of rootstock-scion combination and healing condition on 'Tribute' tomato graft union strength at $20 \mathrm{~d}$ after grafting (DAG) and adventitious root development at 21 DAG for grafted 'Tribute' tomato seedlings in the 2019 experiment.

\begin{tabular}{|c|c|c|}
\hline Treatment $^{\mathrm{z}}$ & Graft union strength $(\mathrm{N})^{\mathrm{y}}$ & Adventitious root rating $(0-10)^{x}$ \\
\hline \multicolumn{3}{|l|}{ Combination } \\
\hline $\mathrm{Sh}+\mathrm{T}$ & $8.42 \mathrm{a}^{\mathrm{w}}$ & $2.2 \mathrm{a}$ \\
\hline $\mathrm{M}+\mathrm{T}$ & $11.17 \mathrm{a}$ & $1.4 \mathrm{~b}$ \\
\hline $\mathrm{T}+\mathrm{T}$ & $9.38 \mathrm{a}$ & $1.8 \mathrm{ab}$ \\
\hline \multicolumn{3}{|l|}{ Healing condition } \\
\hline CL & $10.04 \mathrm{a}$ & $0.3 \mathrm{~b}$ \\
\hline$S$ & $9.28 \mathrm{a}$ & $3.3 \mathrm{a}$ \\
\hline Effect & & $P$ value \\
\hline Combination & 0.072 & 0.018 \\
\hline Healing condition & 0.420 & $<0.001$ \\
\hline Interaction & 0.238 & 0.068 \\
\hline
\end{tabular}

${ }^{\mathrm{z}} \mathrm{Sh}+\mathrm{T}$ = 'Tribute' grafted onto 'Shield'; $\mathrm{M}+\mathrm{T}$ = 'Tribute' grafted onto 'Multifort'; T+T = Self-grafted 'Tribute'; $\mathrm{CL}=$ chamberless healing treatment; $\mathrm{S}=$ standard healing chamber treatment.

${ }^{\mathrm{y}} \mathrm{l} \mathrm{N}=0.2248 \mathrm{lbf}$

${ }^{\mathrm{x}}$ Adventitious roots were evaluated based on the scale created by Meyer et al. (2017), with higher values indicating more severe adventitious root growth. Roots were first classified according to their length: trace roots $(<2 \mathrm{~mm})$, small roots $(2 \mathrm{~mm} \leq$ length $<5 \mathrm{~mm})$, medium roots $(5 \mathrm{~mm} \leq$ length $<10 \mathrm{~mm})$, and large roots $(\geq 10 \mathrm{~mm}) ; 1 \mathrm{~mm}=$ 0.0394 inch. Then each plant was rated using a 0 to 10 scale based on their size, number, and presence in the soil. $0=$ no adventitious roots; $5=1$ large root and any additional roots, but none in the soil; and $10=$ multiple roots in the soil that caused failure of rootstock growth.

${ }^{\mathrm{w}}$ Means followed by the same letter within the same column are not significantly different at $P \leq 0.05$ according to Fisher's least significant difference test.

callus formation and lignification of xylem cells in the graft union area. An interesting observation was that during the test of graft union strength, plant stem integrity was destroyed before the graft union was completely broken in some cases, resulting in the use of additional plants for the test. This phenomenon was only observed in the chamberless healing treatment and primarily for the 'Multifort' grafted plants. This might serve as indirect evidence that the graft union was well healed under chamberless conditions.

GROWTH OF GRAFTED PLANTS. In the 2018 experiment, plant height $(P=0.092)$ and stem diameter $(P=$ 0.073 ) measurements were similar among different healing treatments at 21 DAG (data not shown). In the 2019 experiment, healing treatments affected plant height at 21 DAG (Table 3). Plants healed under standard healing conditions were taller than those in the chamberless healing treatment by $1.2 \mathrm{~cm}(\approx 8 \%)$. However, no difference in plant height between these two healing methods was observed at 27 DAG. There was a significant rootstock-scion combination by healing treatment interaction for stem diameter at 21 DAG $(P=0.006)$ but not at $27 \mathrm{DAG}$ (Table $3)$. At 21 DAG, under standard healing conditions, self-grafted 'Tribute' had larger stem diameter than plants grafted with 'Shield', whereas the latter was larger than plants grafted with 'Multifort'. Under chamberless

Table 3. Effects of rootstock-scion combination and healing condition on grafted 'Tribute' tomato plant height, stem diameter, relative chlorophyll concentration index (SPAD), and leaf number at 21 and $27 \mathrm{~d}$ after grafting (DAG) in the 2019 experiment.

\begin{tabular}{|c|c|c|c|c|c|c|c|c|}
\hline \multirow[b]{2}{*}{ Treatment $^{\mathrm{z}}$} & \multicolumn{2}{|c|}{ Plant ht $(\mathrm{cm})^{\mathrm{y}}$} & \multicolumn{2}{|c|}{ Stem diam $(\mathrm{mm})^{\mathrm{y}}$} & \multicolumn{2}{|c|}{$\begin{array}{l}\text { Relative chlorophyll } \\
\text { concn index (SPAD) } \\
\end{array}$} & \multicolumn{2}{|c|}{ Leaves (no./plant) } \\
\hline & $21 \mathrm{DAG}$ & $27 \mathrm{DAG}$ & $21 \mathrm{DAG}$ & $27 \mathrm{DAG}$ & $21 \mathrm{DAG}$ & $27 \mathrm{DAG}$ & $21 \mathrm{DAG}$ & $27 \mathrm{DAG}$ \\
\hline \multicolumn{9}{|l|}{ Combination } \\
\hline $\mathrm{Sh}+\mathrm{T}$ & $15.3 \mathrm{a}^{\mathrm{x}}$ & $18.2 \mathrm{a}$ & $3.05 \mathrm{ab}$ & $4.14 \mathrm{a}$ & $32.5 \mathrm{~b}$ & $37.0 \mathrm{a}$ & $3.1 \mathrm{a}$ & $4.7 \mathrm{a}$ \\
\hline $\mathrm{M}+\mathrm{T}$ & $14.9 \mathrm{a}$ & $18.3 \mathrm{a}$ & $2.99 \mathrm{~b}$ & $4.12 \mathrm{a}$ & $32.7 \mathrm{ab}$ & $36.2 \mathrm{a}$ & $3.3 \mathrm{a}$ & $4.8 \mathrm{a}$ \\
\hline $\mathrm{T}+\mathrm{T}$ & $15.1 \mathrm{a}$ & $18.4 \mathrm{a}$ & $3.19 \mathrm{a}$ & $3.93 \mathrm{~b}$ & $33.3 \mathrm{a}$ & $36.1 \mathrm{a}$ & $3.3 \mathrm{a}$ & $4.9 \mathrm{a}$ \\
\hline$S$ & $15.7 \mathrm{a}$ & $18.7 \mathrm{a}$ & $3.05 \mathrm{a}$ & $4.12 \mathrm{a}$ & $32.9 \mathrm{a}$ & $35.9 \mathrm{a}$ & $3.3 \mathrm{a}$ & $4.9 \mathrm{a}$ \\
\hline Effect & \multicolumn{8}{|c|}{$P$ value } \\
\hline Combination & 0.660 & 0.908 & 0.045 & 0.026 & 0.037 & 0.383 & 0.323 & 0.164 \\
\hline Healing condition & 0.002 & 0.089 & 0.385 & 0.109 & 0.978 & 0.084 & 0.286 & 0.244 \\
\hline Interaction & 0.830 & 0.662 & 0.006 & 0.522 & 0.861 & 0.965 & 0.628 & 0.361 \\
\hline
\end{tabular}


healing conditions, no differences were observed among different rootstock-scion combinations (data not shown).

When plants were moved to the greenhouse, adventitious roots were not long enough to reach the soil, and they dried out and fell off or stopped growing; generally, no difference was detected between growth of plants with adventitious or without adventitious roots at 21 DAG. More detailed examination is needed to better understand the effects of adventitious root growth during the healing process on plant healing and later growth. It is important to note that longer and more adventitious roots might grow when using different rootstock-scion combinations and, as adventitious roots grow into soil, soilborne pathogens may affect the scion. Limiting adventitious root growth from the scion with the chamberless healing method reduces the need to remove them before transplanting to the field.

No differences in transpiration rate, net $\mathrm{CO}_{2}$ assimilation rate, intercellular $\mathrm{CO}_{2}$ concentration, $g_{\mathrm{S}}$ to $\mathrm{CO}_{2}$, and iWUE were detected among the treatments (Table 4). It has been suggested that rootstock-scion combinations may affect the quality of vascular connection and thus impact water transport (Warschefsky et al., 2016); however, we did not observe a rootstock effect on water transport-related measurements conducted in the present study. If rootstock and scion genotypes are compatible, graft success largely depends on grafting techniques and healing conditions rather than the growth vigor of the rootstock or the scion (Hu et al., 2016). Overall, the chamberless healing treatment did not result in any significant impact on plant growth and the grafted plants had a similar extent of vascular connections as evidenced by the similar transpiration rate compared with the standard healing conditions. At 27 DAG in the 2019 experiment, healing conditions did not affect plant height, stem diameter, SPAD, and leaf number (Table 3), which implied that plants healed under chamberless conditions did not consume more photosynthate reserves during healing and the plants achieved a similar growth rate compared with the standard healing treatment.

At 29 DAG, no significant differences were detected in leaf area, leaf $\mathrm{FW}$, stem $\mathrm{DW}$, and root DW between different treatments (Table $5)$. Self-grafted 'Tribute' and plants grafted with 'Multifort' had a higher leaf number than 'Shield' grafted plants, although the increase was $<6 \%$. By contrast, plants grafted onto 'Shield' showed higher root FW than self-grafted 'Tribute' and plants grafted with 'Multifort'. Healing conditions did not affect leaf number and root FW (Table 5), whereas interactions between healing conditions and rootstock-scion combinations affected stem FW and leaf DW (Table 6). Under chamberless healing conditions, no differences between rootstock-scion combinations were observed. Under standard healing conditions, selfgrafted 'Tribute' and plants grafted onto 'Multifort' had similar stem FW and they were higher than 'Tribute' grafted with 'Shield' by $10.8 \%$ and $7.9 \%$, respectively (Table 6 ).

Rootstock-scion combinations and healing conditions did not affect the time when the first flower opened in grafted tomato plants. At that time, no differences in flower number in the first inflorescence, plant height, and leaf number were detected. 'Tribute' grafted with 'Multifort' had a lower SPAD value compared with plants grafted with self-grafted 'Tribute' and plants grafted with 'Shield' regardless of healing conditions (Table 7). Stem diameter was affected by interactions of rootstock-scion combinations and healing conditions ( $\mathrm{Ta}$ ble 6). Under chamberless condition, 'Tribute' grafted with 'Multifort' showed higher stem diameter than self-grafted 'Tribute' by $5.2 \%$, but these two treatments did not differ from the 'Tribute' grafted with 'Shield'. No difference was detected in standard healing conditions. Overall, chamberless healing did not adversely affect grafted plant growth and flowering during the early stage of establishment.

\section{Conclusions}

In this study, the chamberless healing treatment demonstrated similar survival rate, graft union strength, plant early growth, and flowering time compared with other healing methods involving a relatively humid

Table 4. Effects of rootstock-scion combination and healing condition on grafted 'Tribute' tomato plant transpiration rate $(\mathrm{E})$, net carbon dioxide $\left(\mathrm{CO}_{2}\right)$ assimilation rate $(\mathrm{A})$, intercellular $\mathrm{CO}_{2}$ concentration $(\mathrm{Ci})$, stomatal conductance to $\mathrm{CO}_{2}(g \mathrm{~s})$, and instantaneous water use efficiency (iWUE) measured at 27 and $28 \mathrm{~d}$ after grafting in the 2019 experiment.

\begin{tabular}{|c|c|c|c|c|c|}
\hline Treatment $^{\mathrm{z}}$ & $\begin{array}{c}\mathrm{E}\left[\mathrm{H}_{2} \mathrm{O}\right. \\
\left.\left(\mathrm{mmol} \cdot \mathrm{m}^{-2} \cdot \mathrm{s}^{-1}\right)\right] \\
\end{array}$ & $\begin{array}{c}\mathrm{A}\left[\mathrm{CO}_{2}\right. \\
\left.\left(\mu \mathrm{mol} \cdot \mathrm{m}^{-2} \cdot \mathrm{s}^{-1}\right)\right]\end{array}$ & $\begin{array}{c}\mathrm{Ci}\left[\mathrm{CO}_{2}\right. \\
\left.\left(\mu \mathrm{mol} \cdot \mathrm{mol}^{-1} \text { air }\right)\right]\end{array}$ & $\left(\mathrm{mol} \cdot \mathrm{m}^{-2} \cdot \mathrm{s}^{-1}\right)$ & $\begin{array}{c}\mathrm{iWUE}\left[\mathrm{CO}_{2}\right. \\
\left.\left(\mu \mathrm{mol} \cdot \mathrm{mmol}^{-1} \mathrm{H}_{2} \mathrm{O}\right)\right]\end{array}$ \\
\hline \multicolumn{6}{|l|}{ Combination } \\
\hline $\mathrm{Sh}+\mathrm{T}$ & $4.37 \mathrm{a}^{\mathrm{y}}$ & $17.71 \mathrm{a}$ & $308.58 \mathrm{a}$ & $0.24 \mathrm{a}$ & $4.32 \mathrm{a}$ \\
\hline $\mathrm{M}+\mathrm{T}$ & $4.88 \mathrm{a}$ & $17.98 \mathrm{a}$ & $317.12 \mathrm{a}$ & $0.27 \mathrm{a}$ & $3.95 \mathrm{a}$ \\
\hline $\mathrm{T}+\mathrm{T}$ & $4.15 \mathrm{a}$ & $17.26 \mathrm{a}$ & $306.06 \mathrm{a}$ & $0.22 \mathrm{a}$ & $4.41 \mathrm{a}$ \\
\hline \multicolumn{6}{|l|}{ Healing condition } \\
\hline Effect & & & $P$ value & & \\
\hline Combination & 0.162 & 0.404 & 0.310 & 0.103 & 0.416 \\
\hline Healing condition & 0.669 & 0.092 & 0.693 & 0.533 & 0.813 \\
\hline Interaction & 0.140 & 0.198 & 0.291 & 0.203 & 0.242 \\
\hline
\end{tabular}


Table 5. Effects of rootstock-scion combination and healing condition on grafted 'Tribute' tomato leaf number, leaf area, leaf and root fresh weight (FW), and stem and root dry weight (DW) at $29 \mathrm{~d}$ after grafting in the 2019 experiment.

\begin{tabular}{|c|c|c|c|c|c|c|}
\hline Treatment $^{\mathrm{z}}$ & $\begin{array}{c}\text { Leaves } \\
\text { (no./plant) }\end{array}$ & $\begin{array}{l}\text { Leaf area } \\
\left(\mathrm{cm}^{2} / \text { plant }\right)^{y}\end{array}$ & 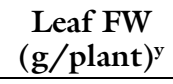 & $\begin{array}{l}\text { Root FW } \\
\text { (g/plant) }\end{array}$ & $\begin{array}{l}\text { Stem DW } \\
\text { (g/plant) }\end{array}$ & $\begin{array}{l}\text { Root DW } \\
\text { (g/plant) }\end{array}$ \\
\hline \multicolumn{7}{|l|}{ Combination } \\
\hline $\mathrm{Sh}+\mathrm{T}$ & $5.1 \mathrm{~b}^{\mathrm{x}}$ & $141.14 \mathrm{a}$ & $4.41 \mathrm{a}$ & $2.99 \mathrm{a}$ & $0.20 \mathrm{a}$ & $0.22 \mathrm{a}$ \\
\hline $\mathrm{M}+\mathrm{T}$ & $5.3 \mathrm{a}$ & $146.38 \mathrm{a}$ & $4.50 \mathrm{a}$ & $2.66 \mathrm{~b}$ & $0.20 \mathrm{a}$ & $0.20 \mathrm{a}$ \\
\hline $\mathrm{T}+\mathrm{T}$ & $5.4 \mathrm{a}$ & $143.20 \mathrm{a}$ & $4.45 \mathrm{a}$ & $2.68 \mathrm{~b}$ & $0.20 \mathrm{a}$ & $0.21 \mathrm{a}$ \\
\hline \multicolumn{7}{|l|}{ Healing condition } \\
\hline Effect & \multicolumn{6}{|c|}{$P$ value } \\
\hline Combination & 0.020 & 0.395 & 0.758 & 0.011 & 0.973 & 0.090 \\
\hline Healing condition & 0.264 & 0.394 & 0.162 & 0.362 & 0.888 & 0.480 \\
\hline Interaction & 0.664 & 0.333 & 0.158 & 0.413 & 0.390 & 0.451 \\
\hline
\end{tabular}

Table 6. Interaction effects of healing condition and rootstock-scion combination on grafted 'Tribute' tomato stem fresh weight (FW) and leaf dry weight (DW) at $29 \mathrm{~d}$ after grafting, and stem diameter when the first flower opened in the 2019 experiment.

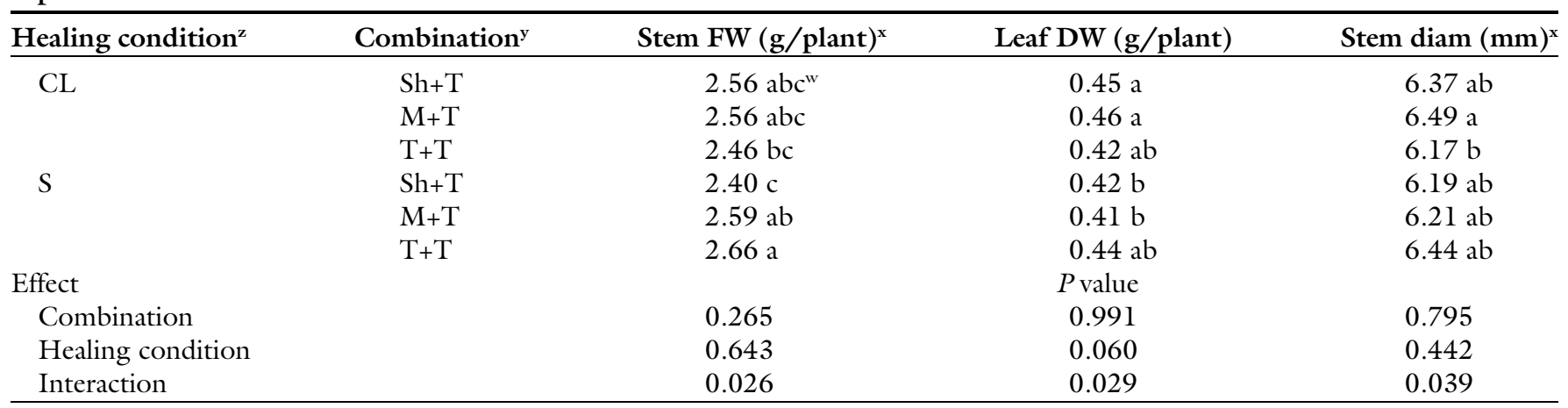

${ }^{\mathrm{z}} \mathrm{CL}=$ chamberless healing treatment; $\mathrm{S}=$ standard healing chamber treatment.

${ }^{y_{S}} \mathrm{Sh}+\mathrm{T}=$ 'Tribute' grafted onto 'Shield'; $\mathrm{M}+\mathrm{T}=$ = 'Tribute' grafted onto 'Multifort'; $\mathrm{T}+\mathrm{T}=$ Self-grafted 'Tribute'.

${ }^{\mathrm{x}} \mathrm{l} \mathrm{g}=0.0353 \mathrm{oz}, 1 \mathrm{~mm}=0.0394$ inch.

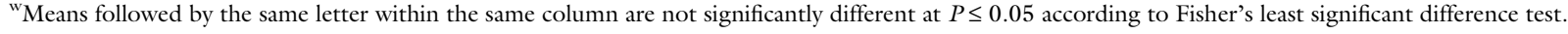

Table 7. Effects of rootstock-scion combination and healing condition on grafted 'Tribute' tomato flowering time, flower number in the first inflorescence, plant height, leaf number, and relative chlorophyll concentration index (SPAD) when the first flower opened in the 2019 experiment.

\begin{tabular}{|c|c|c|c|c|c|}
\hline Treatment $^{\mathrm{z}}$ & $\begin{array}{c}\text { Flowering time } \\
(\mathrm{DAG})^{\mathrm{y}}\end{array}$ & $\begin{array}{c}\text { Flower } \\
\text { (no./plant) }\end{array}$ & Plant ht $(\mathrm{cm})^{\mathrm{x}}$ & $\begin{array}{c}\text { Leaves } \\
\text { (no./plant) }\end{array}$ & $\begin{array}{l}\text { Relative chlorophyll } \\
\text { concn index (SPAD) }\end{array}$ \\
\hline \multicolumn{6}{|l|}{ Combination } \\
\hline $\mathrm{M}+\mathrm{T}$ & $49.6 \mathrm{a}$ & $4.4 \mathrm{a}$ & $90.4 \mathrm{a}$ & $22.0 \mathrm{a}$ & $49.9 \mathrm{~b}$ \\
\hline $\mathrm{T}+\mathrm{T}$ & $48.8 \mathrm{a}$ & $4.4 \mathrm{a}$ & $86.0 \mathrm{a}$ & $20.8 \mathrm{a}$ & $51.3 \mathrm{a}$ \\
\hline \multicolumn{6}{|l|}{ Healing condition } \\
\hline Effect & & & $P$ value & & \\
\hline Combination & 0.581 & 0.634 & 0.326 & 0.588 & 0.050 \\
\hline Healing condition & 0.326 & 0.428 & 0.502 & 0.384 & 0.878 \\
\hline Interaction & 0.186 & 0.777 & 0.816 & 0.626 & 0.887 \\
\hline
\end{tabular}


environment for a period of time and more attentive management of environmental conditions. In general, the two types of rootstocks, which have varying levels of growth vigor, resulted in similar growth of grafted tomato plants in both chamberless and standard healing treatments. Additionally, chamberless healing effectively prevented the emergence and growth of adventitious roots at the graft union, which helped minimize the risk of scion rooting in grafted tomato production. The next step to refine the chamberless healing method could involve assessment of the seedling stage at grafting and examination of a light source and intensity adjustment to further improve graft healing quality. Although more studies are warranted to test and refine the chamberless healing protocol with various rootstock-scion combinations and indoor settings, this unique approach proposed for small growers to more conveniently manage the healing process of grafted tomato plants holds great promise for introducing grafting technology to operators of small and local farms who are interested in economically producing grafted transplants on their own.

\section{Literature cited}

Bausher, M.G. 2013. Graft angle and its relationship to tomato plant survival. HortScience 48:34-36, doi: 10.21273/ HORTSCI.48.1.34.

Buajaila, F.A., P. Devi, and C.A. Miles. 2018. Effect of environment on survival of eggplant, pepper, and tomato in a small-scale healing chamber. HortTechnology 28:668-675, doi: 10.21273/ HORTTECH04103-18.

Fan, J., R. Yang, X. Li, W. Zhao, F. Zhao, and S. Wang. 2015. The processes of graft union formation in tomato. Hort. Environ. Biotechnol. 56:569-574, doi: 10.1007/ s13580-015-0009-1.

Fernández-García, N., M. Carvajal, and E. Olmos. 2004. Graft union formation in tomato plants: Peroxidase and catalase involvement. Ann. Bot. 93:53-60, doi: $10.1093 / \mathrm{aob} / \mathrm{mch} 014$.
Gago, J., C. Douthe, I. Florez-Sarasa, J.M. Escalona, J. Galmes, A.R. Fernie, J. Flexas, and H. Medrano. 2014. Opportunities for improving leaf water use efficiency under climate change conditions. Plant Sci. 226:108-119, doi: 10.1016/ j.plantsci.2014.04.007.

Guan, W. and S. Hallett. 2016. Techniques for tomato grafting. Purdue Ext. HO-260-W.

Hu, B., M.A. Bennett, and M.D. Kleinhenz. 2016. A new method to estimate vegetable seedling vigor, piloted with tomato, for use in grafting and other contexts. HortTechnology 26:767-775, doi: 10.21273/HORTTECH03485-16.

$\mathrm{Hu}, \mathrm{B} ., \mathrm{P}$. Ling, and M. Kleinhenz. 2015. Grafted tomato propagation: Effects of light intensity and temperature on graft healing and plant regrowth. Acta Hort. 1140:327-330, doi: 10.17660/ActaHortic.2016.1140.72.

Johnson, S., C. Miles, P. Kreider, and J. Roozen. 2016. Vegetable grafting: The healing chamber. Washington State Univ. Ext. Fact Sheet. FS051E.

Johnson, S.J. and C.A. Miles. 2011. Effect of healing chamber design on the survival of grafted eggplant, tomato, and watermelon. HortTechnology 21:752758 , doi: $10.21273 / \mathrm{HORTTECH}$. 21.6.752.

Kubota, C., M.A. McClure, N. KokalisBurelle, M.G. Bausher, and E.N. Rosskopf. 2008. Vegetable grafting: History, use, and current technology status in North America. HortScience 43:1664-1669, doi: 10.21273/HORTSCI.43.6.1664.

Lee, K.M., C.S. Lim, S. Muneer, and B.R. Jeong. 2016. Functional vascular connections and light quality effects on tomato grafted unions. Scientia Hort. 201:306317, doi: 10.1016/j.scienta.2016.02.013

Martínez-Ballesta, M.C., C. AlcarazLópez, B. Muries, C. Mota-Cadenas, and M. Carvajal. 2010. Physiological aspects of rootstock-scion interactions. Scientia Hort. 127:112-118, doi: 10.1016/j.scienta. 2010.08.002.

Masterson, S.A., M.M. Kennelly, R.R. Janke, and C.L. Rivard. 2016. Microclimate and scion leaf removal to improve the success of grafted tomato seedlings. HortTechnology 26:261-269, doi: 10.21273/ HORTTECH.26.3.261.
Meyer, L.J., M.M. Kennelly, E.D. Pliakoni, and C.L. Rivard. 2017. Leaf removal reduces scion adventitious root formation and plant growth of grafted tomato. Scientia Hort. 214:147-157, doi: 10.1016/j.scienta.2016.11.019.

Oda, M. 2007. Vegetable seedling grafting in Japan. Acta Hort. 759:175-180, doi: 10.17660/ActaHortic.2007.759.13.

Singh, H., P. Kumar, S. Chaudhari, and M. Edelstein. 2017. Tomato grafting: A global perspective. HortScience 52:13281336, doi: 10.21273/HORTSCI1 199617.

Turquois, N. and M. Malone. 1996. Nondestructive assessment of developing hydraulic connections in the graft union of tomato. J. Expt. Bot. 47:701-707, doi: 10.1093/jxb/47.5.701.

Vu, N.T., Z.H. Xu, Y.S. Kim, H.M. Kang, and I.S. Kim. 2014. Effect of nursery environmental condition and different cultivars on survival rate of grafted tomato seedling. Acta Hort. 1037:765-770, doi: 10.17660/ActaHortic.2014.1037.100.

Warschefsky, E.J., L.L. Klein, M.H. Frank, D.H. Chitwood, J.P. Londo, E.J.B. von Wettberg, and A.J. Miller. 2016. Rootstocks: Diversity, domestication, and impacts on shoot phenotypes. Trends Plant Sci. 21:418-437, doi: 10.1016/j.tplants.2015.11.008.

Wei, H., S. Muneer, A. Manivannan, Y. Liu, J.E. Park, and B.R. Jeong. 2018. Slight vapor deficit accelerates graft union healing of tomato plug seedling. Acta Physiol. Plant. 40:147, doi: 10.1007/ s11738-018-2724-6.

Yang, H., M.K. Shukla, X. Mao, S. Kang, and T. Du. 2019. Interactive regimes of reduced irrigation and salt stress depressed tomato water use efficiency at leaf and plant scales by affecting leaf physiology and stem sap flow. Front. Plant Sci. 10: doi: $10.3389 /$ fpls.2019.00160.

Yin, H., B. Yan, J. Sun, P.F. Jia, Z.J. Zhang, X.S. Yan, J. Chai, Z.Z. Ren, G.C. Zheng, and H. Liu. 2012. Graft-union development: A delicate process that involves cell-cell communication between scion and stock for local auxin accumulation. J. Expt. Bot. 63:4219-4232, doi: 10.1093/jxb/ers109. 